\title{
Milk Production from Holstein Half Udders After Concurrent Thirty- and Seventy-Day Dry Periods*'†
}

\author{
M. S. Gulay, ${ }^{1}$ M. J. Hayen, ${ }^{2}$ H. H. Head, ${ }^{2}$ C. J. Wilcox, ${ }^{2}$ and K. C. Bachman ${ }^{2}$ \\ ${ }^{1}$ Department of Physiology, Burdur Veterinary Faculty, Akdeniz University, Turkey \\ ${ }^{2}$ Department of Animal Sciences, University of Florida, Gainesville 32611
}

\begin{abstract}
The objective of this study was to use a within-cow, half-udder model to compare the effect of cessation of milk removal from mammary quarters within respective half udders at either 30 or $70 \mathrm{~d}$ before expected calving date (ECD) on the ability of the half udders to subsequently produce milk. Pregnant Holstein cows were assigned to control $(\mathrm{n}=14)$ or treatment (TRT, $\mathrm{n}=26$ ) groups. All mammary quarters in the udder of cows in the control group had 70-d ( $68 \pm 9 \mathrm{~d})$ dry periods, whereas in each cow of the TRT group, 1 randomly selected half udder was dried at $70 \mathrm{~d}$ before ECD and the other half udder continued to be milked twice daily until dried at $30 \mathrm{~d}$ before ECD. From 80 through $70 \mathrm{~d}$ before ECD, amounts of milk produced by the left and right half udders of cows in the TRT group were measured at the first-shift milking. No differences were detected in the actual or relative amounts of milk produced by the left $(3.46 \pm 0.2 \mathrm{~kg} ; 48.8 \pm 1.0 \%)$ and the right ( $3.63 \pm 0.2 \mathrm{~kg} ; 51.2 \pm 1.0 \%)$ half udders. Furthermore, the actual and relative amounts of milk produced by the half udders ( $\mathrm{n}=12$ left, 14 right) subsequently dry for $67 \pm 7 \mathrm{~d}(3.56 \pm 0.2 \mathrm{~kg} ; 50.2 \pm 1.0 \%)$ and the half udders ( $\mathrm{n}=14$ left, 12 right) subsequently dry for $27 \pm 7 \mathrm{~d}(3.54 \pm 0.2 \mathrm{~kg} ; 49.8 \pm 1.0 \%)$ did not differ before they were dried. However, from 3 to $100 \mathrm{~d}$ of the subsequent lactation, the 30 -d dry half udders produced $18.9 \%$ less milk than the 70 -d dry half udders ( 16.3 vs. $20.1 \pm 1.0 \mathrm{~kg} / \mathrm{d})$. In addition, relative amounts of totaludder milk produced by the 30 - and 70-d dry half udders in the same cow differed ( 44.9 vs. $55.1 \pm 0.2 \%$, respectively). Cows in the control group produced more milk than cows in the TRT group through 80 DIM (39.5 vs. $35.2 \pm 0.6 \mathrm{~kg} / \mathrm{d})$, but not from 3 through 150 DIM (39.0
\end{abstract}

Received November 8, 2004

Accepted July 29, 2005.

Corresponding author: K. C. Bachman; e-mail: bachman@animal. ufl.edu.

*Florida Agricultural Experiment Station Journal Series Number R-09805.

$\dagger$ Mention of companies or products does not constitute endorsement by University of Florida or Florida Agricultural Experiment Station over similar products not mentioned. vs. $36.2 \pm 1.6 \mathrm{~kg} / \mathrm{d})$. Thus, half udders that produced the same actual and relative amounts of milk before being dried did not do so when given a 30-d dry period instead of a 70-d dry period. When compared with the pre-dry value (49.8\%), the relative contribution of half udders dry for $30 \mathrm{~d}$ to the total milk yield during the first 100 DIM was decreased by $9.8 \%$.

(Key words: dry period, milk yield, days dry, half udder)

Abbreviation key: ECD = expected calving date, $\mathbf{C M}=$ continuously milked, $\mathbf{M E}=$ mature equivalent, MEC = mammary epithelial cells, $\mathbf{M Y}=$ milk yield, TRT $=$ treatment.

\section{INTRODUCTION}

Results of recent between-cow experiments led to the conclusion that modern multiparous dairy cows do not require a dry period longer than 28 to $35 \mathrm{~d}$ (Schairer, 2001; Bachman, 2002; Gulay et al., 2003; Annen et al., 2004b; Rastani et al., 2005). During ensuing lactations, milk production did not differ for cows with short dry periods compared with cows with traditional 50- to 60d dry periods. The traditional dry period lengths were considered optimal based largely on the retrospective analysis of accumulated milk production records rather than on the results obtained from designed animal experiments (Bachman and Schairer, 2003; Grummer and Rastani, 2004; Kuhn and Hutchison, 2005).

A within-cow, half-udder experimental approach was used to compare the effects of continuous milking (CM, $0 \mathrm{~d}$ dry) and a 60-d dry period on subsequent milk production (Smith et al., 1967). They reported that the contralateral mammary quarters of the CM cows subsequently produced 38 and $44 \%$ less milk than the other 2 mammary quarters within the same udder not milked for $60 \mathrm{~d}$ before parturition. The half-udder experimental model eliminated all genetic, endocrine, and nutritional factors, and most of the management factors that can affect subsequent milk production (Bachman and Schairer, 2003). Thus, the advantage of using a halfudder model to compare the effect of different dry period lengths on milk production should be a decrease in 
between-animal variation, thereby reducing the number of dairy cows required to identify the optimal lengths of dry periods for current dairy cows that may vary in parity and management (Annen et al., 2004a).

Our objective was to use the within-cow, half-udder model to compare the effects of cessation of milk removal from the 2 mammary quarters in half udders of the same cow at 30 or $70 \mathrm{~d}$ before expected calving date (ECD) on the ability of the half udders to subsequently produce milk. For comparison, milk yield (MY) was measured in a group of 14 cows in which all 4 quarters in the udder received a 70-d dry period.

\section{MATERIALS AND METHODS}

\section{Experimental Design and Animals}

Pregnant Holstein cows were assigned randomly to control $(\mathrm{n}=14)$ and treatment (TRT, $\mathrm{n}=26)$ groups at approximately $85 \mathrm{~d}$ before their ECD. Parity of cows for the experimental lactation ranged from 2 to 8 , but parity of all cows was 4 or less except for 3 cows in the TRT group whose parities were 5,6 , and 8 . There were 2 and 9 primiparous cows assigned to the control and TRT groups, respectively. Previous mean 305-d mature equivalent (ME) lactation MY of the control and TRT groups of cows did not differ $(10,669 \pm 472$ vs. 10,977 $\pm 433 \mathrm{~kg} ; P>0.10$ ), and neither the previous lactation DIM nor the actual milk production differed. All mammary quarters in the udder of cows in the control group were allowed a 70-d dry period. In contrast, at $70 \mathrm{~d}$ before ECD, milk removal from the 2 mammary quarters on the same side of the udder (half udder) of each cow in the TRT group was discontinued but removal of milk from the other 2 mammary quarters of the opposite side (half udder) continued until $30 \mathrm{~d}$ before ECD. Thus, of the 4 mammary quarters within a TRT group cow, 2 mammary quarters on the same side of the udder were dry for 70 or $30 \mathrm{~d}$ before the parturition that initiated the subsequent lactation.

\section{Feeding Management}

At $70 \mathrm{~d}$ before ECD, cows in the control group were dried, and then were moved to a dry-herd lot and fed a far-off dry-herd diet. At $30 \mathrm{~d}$ before their ECD, the cows in the control group were moved to a close-up dry lot and fed an anionic ( $-13 \mathrm{mEq} / 100 \mathrm{~g}$ of DM) close-up dry-cow diet until parturition (Gulay et al., 2004). Upon cessation of milk removal from 1 half udder at $70 \mathrm{~d}$ before ECD, cows in the TRT group remained in the milking herd and continued to consume the milkingherd TMR until the remaining half udder was dried at $30 \mathrm{~d}$ before the ECD. Then, these newly-dried cows from the TRT group were transferred directly to the close- up dry-cow lot where they were managed with the cows from the control group that were also within $30 \mathrm{~d}$ of ECD. After parturition, all cows were managed in the same free-stall barn and consumed a TMR based on corn silage, whole cottonseeds, and grain concentrate (Gulay et al., 2004).

\section{$B C S$ and BW}

After parturition and through $100 \mathrm{~d}$ postpartum, BCS (1 to 5, thin to fat, respectively; Ferguson et al., 1994) and BW of cows were recorded weekly on a fixed day, before the a.m. feeding and first-shift milking.

\section{Milk Removal and Measurement}

All cows in the TRT group were switched from $3 \times$ to $2 \times / \mathrm{d}$ milking at $80 \mathrm{~d}$ before ECD. On this schedule, cows were milked at the end of the first $(1000 \mathrm{~h})$ and third $(0100 \mathrm{~h})$ milking shifts which gave daily milking intervals of 9 and $15 \mathrm{~h}$. From 80 through $70 \mathrm{~d}$ before ECD, MY from the left and right half udders of each cow in the TRT group were measured during the first-shift milking $(\mathrm{n}=486)$. One half udder within each cow of the TRT group was selected randomly to be dried. All mammary quarters of cows in the control group were dried at $70 \mathrm{~d}$ before ECD. From 70 through $30 \mathrm{~d}$ before ECD, the MY of the other half udder continued to be recorded at each milking and then it was also dried. A commercial antibiotic preparation was infused into quarters at the milking during which they were dried. The dry-off treatment coupled with teat dipping and milking parlor hygiene were apparently effective, as only 1 incidence of mastitis each in 4 of the 26 cows in the TRT group was observed, and only 1 of those had mastitis in 1 quarter of the half udder given a 30-d dry period. In the control group, only 2 cows had mastitis, but 1 of those cows had 4 instances across 2 quarters.

Birth weight of calves was recorded within $12 \mathrm{~h}$ of birth. Yields of first-milking colostrum from cows in the control group and from each half udder of the cows in the TRT group were measured and collected. The concentration of antibody in each colostrum sample was estimated using a colostrometer (Nasco, Fort Atkinson, WI). From 3 to $100 \mathrm{~d}$ postpartum, the MY of the half udders in the TRT group of cows that had been dry for 70 or $30 \mathrm{~d}$ were measured during both milking shifts on $3 \mathrm{~d}$ each week (Monday, Wednesday, and Friday). However, total milk production was recorded daily through 150 DIM for all cows in both the control and TRT groups. Starting at 80 DIM, all cows were supplemented with bST (Posilac; 500 mg; Monsanto, St. Louis, MO) every other week. Beyond 100 DIM all cows were milked $3 \times / \mathrm{d}$ with 8 -h intervals between each milking. 
The milking-unit claw assemblies ( $\mathrm{Rx}$ manifold, model no. 36369, Westfalia-Surge Inc., Galesville, WI) designed to separate the milk removed from each mammary quarter of the udder were used on the $3 \mathrm{~d}$ each week when MY from both half udders of the TRT cows were measured simultaneously. Milk from the left half udder was measured using a Tru-test milk meter (Babson Bros., Naperville, IL) as it was removed but before it was combined with the milk being removed from the right half udder. The combined milk from the left and right half udders then flowed through the milking parlor meter where the total weight of milk at that milking for each cow in the TRT group was recorded. The difference between the milking parlor meter and Tru-test milk meter measurements was the weight of milk from the right half udder. Before beginning the experiment, the accuracy of this method to obtain milk weights for the 2 half udders was evaluated and verified. A highly significant correlation was obtained between the total MY values obtained with the Tru-test milk meters and the milking parlor meters $(\mathrm{n}=134, \mathrm{r}=0.95)$.

To ensure that the milk removal schedule and collection of MY data from each of the half udders were performed correctly, a team composed of 3 of the authors milked all cows through 100 DIM. This schedule was in effect from August 2002 until March 2003. This need for personal involvement dictated the choice of the $2 \times /$ $\mathrm{d}$ milking schedule and the collection of the half-udder MY data 3 times a week. The experimental cows were milked at the end of 2 of the 3 daily milking shifts used for the research unit herd. This ensured that saleable milk would not be contaminated in the event that an attachment of the milking assembly to a half udder was made incorrectly (i.e., attached on a half udder that had been dried-off and infused with antibiotics at $70 \mathrm{~d}$ before ECD). This cautionary measure, in turn, dictated the unequal time intervals that existed between the 2 daily milking shifts.

\section{Statistical Analyses}

Data for the pre- and postdry period phases were analyzed separately. The Proc GLM least squares ANOVA (SAS Institute, 1991) was used to analyze data for BW, BCS, and MY responses for the cows in the control and TRT groups, and for MY of the 30- and 70d-dry half udders of cows in the TRT group. Various periods that had physiological importance in interpreting results from 3 to 150 DIM were evaluated (3 to 80 DIM, 3 to 100 DIM, 80 to 100 DIM, 80 to 150 DIM, 100 to 150 DIM, and 3 to 150 DIM). Effects of parity of cows in the 2 experimental groups were evaluated. To estimate the individual daily or weekly least squares means for each response variable and treatment, the
MIXED procedure of SAS was used (Littell et al., 2000). Thus, for the between-cow group comparison of each response variable, the mathematical model included the main effects of treatment (control vs. TRT), cow nested in treatment [Cow (TRT)], and experimental day or week, to the highest significant order of curvilinearity. In some analyses the previous 305-d ME lactation MY of cows was used as a covariate.

For the within-cow comparisons of the MY response, mathematical models included the main effects of halfudder side (left vs. right; S), dry period length (30 vs. $70 \mathrm{~d}$; D), the interaction of half udder and dry period length $(\mathrm{S} \times \mathrm{D})$, using [Cow $(\mathrm{S} \times \mathrm{D})$ ] as the error term and experimental day or week to the highest significant order.

\section{RESULTS}

\section{Actual Days Dry and Calf Birth Weights}

Cessation of milk removal occurred at $70 \mathrm{~d}$ before ECD for cows in the control group and for one half udder of each cow in the TRT group. Removal of milk from the remaining half udder was stopped at $30 \mathrm{~d}$ before ECD. Actual time dry for cows in the control group $(n=14)$ and the 70-d-dry half udders of the TRT group cows $(\mathrm{n}=26)$ were $68 \pm 9 \mathrm{~d}$ and $67 \pm 7 \mathrm{~d}$, and did not differ $(P=0.91)$. The actual days dry for the 30-d-dry half udders of cows in the TRT group was 27 $\pm 7 \mathrm{~d}$. For cows in the TRT group, the actual days dry ranged from 20 to $36 \mathrm{~d}$ and had the following distribution: 20 to $24 \mathrm{~d}$ dry $(\mathrm{n}=6), 25$ to $29 \mathrm{~d}$ dry $(\mathrm{n}=12)$, and 30 to $36 \mathrm{~d}$ dry $(n=8)$. Mean birth weights of calves delivered by cows in the control and TRT groups did not differ ( 39.1 vs. $37.5 \mathrm{~kg}, P=0.30$ ).

\section{Changes in BW and BCS}

No treatment effect was detected between the control and TRT groups of cows for BW at parturition and through 60 or 100 DIM (Table 1). However, as expected, mean BW decreased sharply after parturition in both groups of cows $(P<0.01$; Figure 1$)$, but means and trends for the control and TRT groups of cows did not differ (Figure 1). The decrease in BW continued through 4 to 5 wk of lactation, after which cows in both groups began to regain BW (Figure 1).

The BCS at parturition for cows in the control and TRT groups did not differ (3.57 vs. 3.52, $P=0.64$ ). However, treatment effects tended to be significant for the first 60 and $100 \mathrm{DIM}(P \leq 0.10$; Table 1$)$; control cows tended to have lower BCS. As expected, a curvilinear (cubic) effect of week on BCS was detected $(P<0.01$, Figure 2). In general, changes in BCS that occurred after parturition followed the same pattern observed 
Table 1. Least squares means and SE for BW and BCS of Holstein cows in the control and treatment groups.

\begin{tabular}{llllllll}
\hline & \multicolumn{3}{c}{ BW $(\mathrm{kg})$} & & \multicolumn{3}{c}{ BCS $^{1}$} \\
\cline { 2 - 3 } Interval & Control & Treatment & $P=$ & & Control & Treatment & $P=$ \\
\hline Calving & $672 \pm 13$ & $696 \pm 14$ & 0.26 & & $3.57 \pm 0.09$ & $3.52 \pm 0.06$ & 0.64 \\
0 to 60 DIM & $648 \pm 13$ & $661 \pm 14$ & 0.60 & & $3.15 \pm 0.08$ & $3.31 \pm 0.05$ & 0.09 \\
0 to 100 DIM & $655 \pm 13$ & $677 \pm 10$ & 0.25 & & $3.19 \pm 0.08$ & $3.35 \pm 0.05$ & 0.10 \\
\hline
\end{tabular}

${ }^{1}$ Scale of 1 to 5 , from thin to fat; Ferguson et al., 1994.

for BW. The decrease in BCS continued until about 5 to 6 wk postpartum and was followed by a slow increase throughout the remainder of the 150-d period. Mean BCS was maintained at $>3.0$ for cows in both groups but scores tended to be slightly higher in the cows in the TRT group through $15 \mathrm{wk}$ of lactation (Figure 2).

\section{Milk Yield}

Pre-dry period. From 80 to $70 \mathrm{~d}$ before ECD, MY from the left and right half udders of all cows in the TRT group ( $\mathrm{n}=26$ ) were measured during the firstmilking shift. Amount of milk and the percentage distribution of the total-udder milk produced by the 26 left $(3.46 \pm 0.22 \mathrm{~kg} ; 48.8 \pm 0.98 \%)$ and the 26 right $(3.63 \pm$ $0.20 \mathrm{~kg} ; 51.2 \pm 1.01 \%)$ half udders did not differ $(P=$ 0.56; Table 2). After random assignment of these half udders to either the 70-d ( $\mathrm{n}=12$ left; 14 right) or $30-\mathrm{d}$ ( $\mathrm{n}=14$ left, 12 right) dry period lengths, the MY data were analyzed. Results of half-udder MY from 80 to 70 $\mathrm{d}$ before ECD showed that for the 26 half udders assigned to the $70-\mathrm{d}(3.56 \pm 0.21 \mathrm{~kg} ; 50.2 \pm 0.99 \%)$ or 30 $\mathrm{d}$ dry periods $(3.54 \pm 0.20 \mathrm{~kg} ; 49.8 \pm 1.00 \%)$, MY did not differ $(P=0.96$; Table 2$)$.

During the 10-d pre-dry period from 80 to $70 \mathrm{~d}$ before ECD, milk production by the half udders subsequently

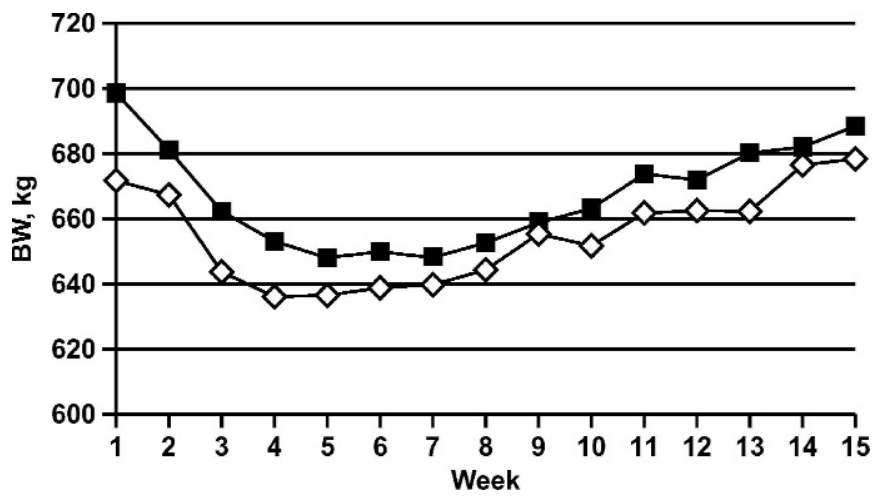

Figure 1. Weekly least squares means for BW of Holstein cows in control $(\diamond)$ and treatment $(\square)$ groups during the early postpartum period. assigned to have 30-d dry periods declined to approximately $3 \mathrm{~kg} / \mathrm{d}$ at the first-shift milking (Figure 3). After the removal of milk from the half udders assigned to 70-d dry periods had ceased, an apparent compensatory increase in milk production was observed for the half udders assigned to 30-d dry periods; the average firstshift milk production increased to around $4 \mathrm{~kg} / \mathrm{d}$ (Figure 3). During the remainder of the pre-dry milking phase through $30 \mathrm{~d}$ before ECD, milk production by half udders assigned to a 30-d dry period decreased to a nadir of around $2 \mathrm{~kg}$ at the first-shift milking.

Post-dry period. The quantity and quality (antibody concentration) of first-milking colostrum was determined for the comparisons between-cow [control $(\mathrm{n}=$ 9) vs. TRT $(n=21)]$ and within-cow [30-d dry half udders $(\mathrm{n}=21)$ vs. $70-\mathrm{d}$ dry half udders $(\mathrm{n}=21)$ ]. No colostrum samples were collected and included in data analysis unless verified to be from the first milking after parturition. No differences in colostrum quantity $(P=0.20)$ or quality $(P=0.30)$ were detected between the control and TRT cows $(6.77 \pm 1.11$ vs. $5.00 \pm 0.77 \mathrm{~kg}$ and 116.5 \pm 6.4 vs. $124.9 \pm 4.1 \mathrm{mg} / \mathrm{mL}$, respectively). Likewise, no differences were detected between the same measures for the 30-d and 70-d dry half udders within cows in the TRT group $(2.17 \pm 0.5$ vs. $2.81 \pm 0.6 \mathrm{~kg}, P=0.30$; $124.9 \pm 3.9$ vs. $125.1 \pm 3.8 \mathrm{mg} / \mathrm{mL}, P=0.90)$.

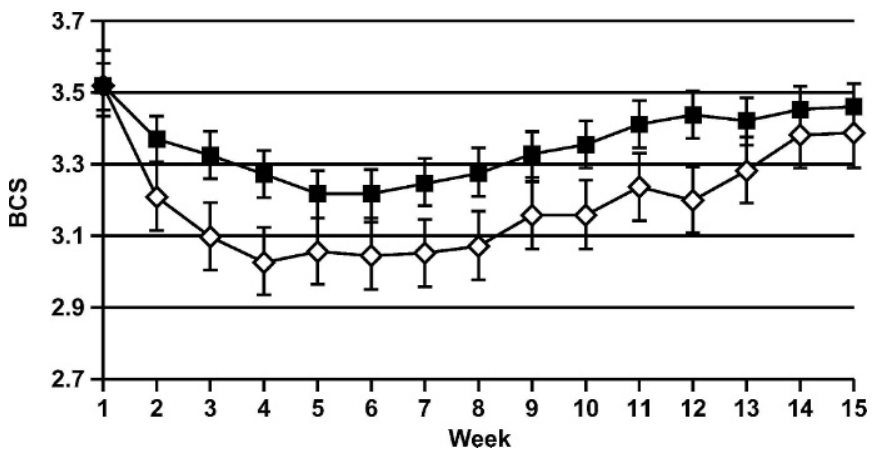

Figure 2. Weekly least squares means and SE for BCS of Holstein cows in control $(\diamond)$ and treatment $(\square)$ groups during the early postpartum period. 
Table 2. Least squares means and SE for yields and distribution percentages of milk removed from Holstein half udders in the pre- and postdry periods. ${ }^{1}$

\begin{tabular}{lllllll}
\hline Milking interval & $\begin{array}{l}\text { Half } \\
\text { udder }\end{array}$ & $\mathrm{n}$ & $\begin{array}{l}\text { Milk yield } \\
(\mathrm{kg})\end{array}$ & $P=$ & $\begin{array}{l}\text { Distribution } \\
(\%)\end{array}$ & $P=$ \\
\hline Pre-dry period: & Left & 26 & $3.46 \pm 0.22$ & 0.56 & $48.8 \pm 0.98$ & 0.56 \\
(80 to 70 d before ECD) $^{2}$ & Right & 26 & $3.63 \pm 0.20$ & & $51.2 \pm 1.01$ & 0.96 \\
& $70-$ d & 26 & $3.56 \pm 0.21$ & 0.96 & $50.2 \pm 0.99$ & \\
& 30-d & 26 & $3.54 \pm 0.20$ & & $49.8 \pm 1.00$ & 0.03 \\
Postdry period: & $70-\mathrm{d}$ & 26 & $20.1 \pm 1.04$ & 0.03 & $55.1 \pm 0.21$ & \\
(3 to 100 DIM) & 30-d & 26 & $16.3 \pm 1.03$ & & $44.9 \pm 0.18$ & \\
\hline
\end{tabular}

${ }^{1}$ Pre-dry period values are based on first-shift milk yields, whereas postdry period values are based on daily milk yields.

${ }^{2} \mathrm{ECD}=$ Expected calving date.

From 3 to 80 DIM, the mean milk production of control cows was higher than that of TRT cows $(39.5 \pm 0.69$ vs. $35.2 \pm 0.50 \mathrm{~kg} / \mathrm{d} ; P<0.01$; Table 3 ). However, the difference in daily mean milk production decreased after wk 7 of lactation $(P<0.05$; Figure 4$)$. During the lactation interval beginning with initiation of bST supplementation ( 80 to $150 \mathrm{DIM}$ ), mean milk production of the cows in the control and TRT groups did not differ ( $38.5 \pm 0.83$ vs. $37.3 \pm 0.78 \mathrm{~kg} / \mathrm{d} ; P=0.25$; Table 3 ). For the lactation period from 3 to $150 \mathrm{DIM}$, no difference in mean milk production between cows in the control and TRT groups was detected ( $39.0 \pm 1.86$ vs. 36.2 $\pm 1.29 \mathrm{~kg} / \mathrm{d} ; P=0.16$; Table 3 ).

For cows in the TRT group, the subsequent mean milk production of the half udders dry for either 30 or $70 \mathrm{~d}$ before ECD differed. The within-cow difference in milk production of the half udders $(19.9 \pm 0.9$ vs. 15.2 $\pm 0.6 \mathrm{~kg} / \mathrm{d}, P<0.01$ ) existed throughout the 3 to $80 \mathrm{DIM}$ comparison period (Figure 5) and for the period 3 to 100 DIM, which included the period of bST supplementation to all cows in the TRT group (20.1 \pm 1.04 vs.16.3 $\pm 1.03 \mathrm{~kg} / \mathrm{d} ; P=0.03$; Table 2). During the $3 \mathrm{wk}$ from beginning of bST supplementation to end of recording half-udder MY (80 to $100 \mathrm{DIM}$ ), the mean milk produc-

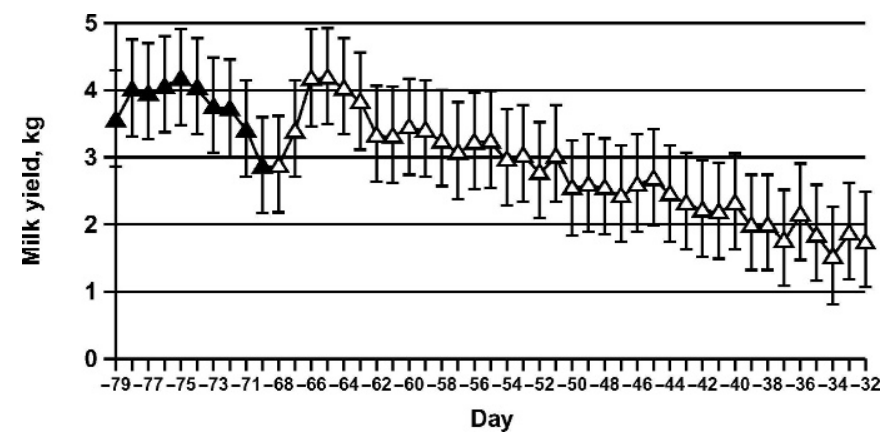

Figure 3. Least squares means and SE for first-shift milk production from 30-d dry half udders of cows in the treatment group before $(\Delta)$ and after $(\triangle)$ milk removal from the 70-d dry half udder stopped. tion of the half udders given 70-d or 30-d dry periods differed $(20.2 \pm 0.4 \mathrm{vs} .16 .9 \pm 0.4 \mathrm{~kg} / \mathrm{d} ; P<0.01)$.

As mentioned above, the possible effects of parity were evaluated. No differences in total mean udder milk production of the cows in the control and TRT groups were observed, even when adjusted for mean ME lactation MY in the previous lactation or when parity was included in the mathematical model used to evaluate the milk production during the different ranges of DIM. Clearly, this is a weak comparison because of the low number of cows $(n=14)$ and the distribution of cows in the 3 parity groups. However, for the TRT cows, total numbers of cows were greater $(n=26)$ and the number of cows with parities 2,3 , or 4 and higher was similar (9, 8, and 9 cows). Furthermore, during the different periods that milk production was evaluated through 3 to $150 \mathrm{DIM}$, the trends in mean milk production for the cows in the 3 parity groups were similar. Comparison of the mean milk production of the 30-d dry and the 70-d dry half udders within the 3 parity groups did not reveal any differences by the respective half udder due to parity. Within the TRT cows, the mean MY and the relative proportion of milk produced by the $30-\mathrm{d}$ (15.9 $\mathrm{kg} / \mathrm{d} ; 43.5 \%$, range 41.6 to $45.1 \%$ ) and the $70-\mathrm{d}$ dry period half udders $(20.7 \mathrm{~kg} / \mathrm{d} ; 56.5 \%$, range 54.9 to $58.4 \%$ ) were similar and showed the same trends across the 3 parity groups. Therefore, we concluded that there were no effects of parity on milk production or relative performance of the half udders in the TRT cows that biased the milk production results obtained or their interpretation.

Table 3. Least squares means and SE for postpartum milk yields of Holstein cows in the control and treatment groups.

\begin{tabular}{llcl}
\hline & \multicolumn{2}{c}{ Milk yield $(\mathrm{kg} / \mathrm{d})$} & \\
\cline { 2 - 3 } DIM & Control & Treatment & $P=$ \\
\hline 3 to 80 & $39.5 \pm 0.69$ & $35.2 \pm 0.50$ & 0.01 \\
80 to 150 & $38.5 \pm 0.83$ & $37.3 \pm 0.78$ & 0.25 \\
3 to 150 & $39.0 \pm 1.86$ & $36.2 \pm 1.29$ & 0.16 \\
\hline
\end{tabular}




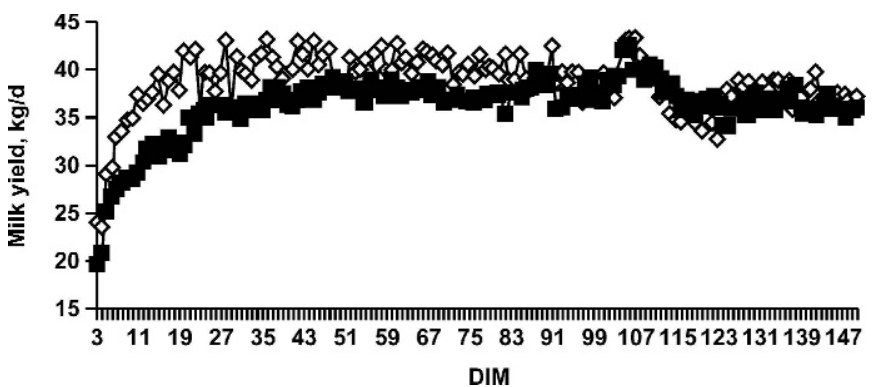

Figure 4. Least squares means for daily milk yields of cows in control $(\diamond)$ and treatment $(\square)$ groups through 150 DIM. Use of bST biweekly began at 80 DIM; switch to $3 \times$ milking began at 100 DIM.

As described, the distribution percentages of the total-udder milk removed during the first-shift milking during the pre-dry period phase (from 80 to $70 \mathrm{~d}$ before ECD) was similar for the half udders assigned to be dry for 70 or $30 \mathrm{~d}$ before ECD (50.2 vs. $49.8 \%$, respectively; $P=0.96$; Table 2). However, based on the mean daily total amount of milk from the half udders during the 2 daily milking shifts through 100 DIM, the 70-d dry half udders subsequently produced a greater proportion of the daily milk than did the 30-d dry half udders (55.1 vs. $44.9 \%$, respectively; $P=0.03$, Table 2 ). There was a $9.8 \%$ decrease in the relative contribution that the 30-d dry half udders made to the total daily amount of milk produced by the half udders of the TRT cows. Thus, half udders apparently capable of producing the same actual and relative amounts of milk before being dried did not do so when the dry period was shorter.

Within the TRT group cows $(\mathrm{n}=26)$, there were 3 cows that produced minimal amounts of milk in the 30$\mathrm{d}$ dry half udders relative to the 70- $\mathrm{d}$ half udders. Their actual dry periods were 21,29 , and $36 \mathrm{~d}$. At 80 DIM,

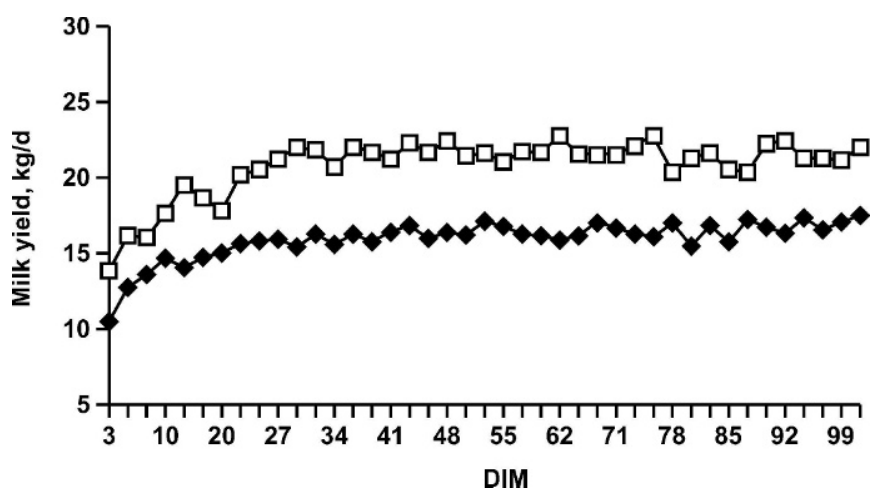

Figure 5. Least squares means for daily milk yields of the 70-d dry $(\square)$ and 30-d dry $(\diamond)$ half udders of treatment group cows through 100 DIM. these 30 -d dry half udders produced only $17.7,19.2$, and 19.1 percentage of the total-udder MY $(15.4,36.3$, and $33.2 \mathrm{~kg} / \mathrm{d}$, respectively). These percentages were considerably less than the average for all 30-d dry half udders $(44.9 \%$, Table 2$)$, and apparently were not affected by actual days dry of 20 to $24(\mathrm{n}=6), 25$ to $29(\mathrm{n}=$ $12)$, or 30 to $36(n=8)$ or to greater disease incidence, in particular mastitis. Importantly, when the data from these 3 cows were not included in statistical analyses, the overall results and interpretation were not changed.

\section{DISCUSSION}

The goal of this research was to evaluate whether cows given a 30-d dry period would produce as much milk during the subsequent lactation as cows given a 70-d dry period. The half-udder experimental model was chosen to make this comparison rather than the between-cow model comparison. Our hypothesis was that if all 4 quarters of the udder within a cow given a 30-d dry period produced as much milk as the 4 mammary quarters within a cow given a 70-d dry period, then the 2 mammary quarters of a half udder given a 30-d dry period should produce as much milk as the 2 mammary quarters in the opposite half udder that had been given a 70-d dry period before ECD. The cows that were assigned randomly to form the 2 groups (control and TRT) had similar mean 305-d ME lactation milk production and DIM during the previous lactation and also low incidences of disease and mastitis that could have affected milk production results differently during the treatment lactation.

To date, use of the within-cow half-udder experimental approach has been limited to comparison of continuous milking (CM, 0-d dry) and 60-d dry periods on milk production of the respective half udders (Smith et al., 1967). They reported that half udders of $3 \mathrm{CM}$ cows subsequently produced 38 and $44 \%$ less milk than the opposite half udders that had the 60-d dry period, but 2 CM cows did produce 97 and $99 \%$ of that produced by the 60-d dry half udder. Factors that could have caused such great differences in response were not identified. A similar disparity in mean milk production response was seen in the current study. In 3 of the 26 cows in the TRT group, the 30-d half udders appeared to be less well developed and they produced much less milk than the half udders given the 70-d dry period. The reasons for this reduced milk production, besides apparent reduced half-udder size, were not because of differences in days dry or to occurrence of either preor postpartum calving-related diseases or mastitis, but likely were due to differences in mammary tissue response to local or systemic factors. 
In contrast to results of within-cow half-udder studies, between-cow studies that compared $0(\mathrm{CM})$ and 60 $\mathrm{d}$ dry period lengths showed that CM multiparous cows had 22\% (Remond et al., 1997), 11\% (Annen et al., 2004b), and 15\% (Rastani et al., 2005) reductions in milk production. Although percentage decreases differed across studies, in general, the mean decreases in milk production responses were less in the betweencow studies.

The validity of the half-udder model has been questioned (Capuco and Akers, 1999; Grummer and Rastani, 2004), but was used because of some apparent advantages (Bachman and Schairer, 2003). Comparison of milk production in the same cow reduces both the between-animal variation and the number of animals needed to detect statistical significance because the genetics, animal management, nutrients ingested, and the concentrations of hormones and growth factors in the peripheral circulation are identical. However, one cannot assume that perfusion and exposure of tissues of both half udders in the same cow to blood-borne factors will be identical where one half udder is dried and the other still is being milked. Moreover, use of this model does not preclude the possibility that local response of mammary tissue to milking induced systemic changes and to milk accumulation or removal from the half udders will cause unexpected differences in mammary cell responses within the respective half udders.

Using the between-cow model to compare 30-d and 60-d dry period lengths in multiparous cows showed that those given the 30-d dry period produced 0 to $3.6 \%$ less milk (Schairer, 2001; Bachman, 2002; Gulay et al., 2003; Annen et al., 2004b; Rastani et al., 2005). Clearly, there was a much greater decrease in mean milk production (18.9\%, Table 2) by the 30-d dry half udder during the current study. This gave rise to a corresponding $9.8 \%$ decrease in the relative amount of total udder milk produced by the 30 -d dry half udder (49.8 vs. 44.9\%; Table 2). Difference in half-udder milk production may represent an actual decrease by the 30-d dry half udder. However, if there were a compensatory increase in milk production by the 70-d dry half udder during the first 100 DIM, it would lead to underestimation of the actual decrease in the 30-d half udder milk production. A small compensatory increase in mean daily milk production was seen in 30-d dry half udders still being milked after the 70-d half udder was dried-off (Figure 3). Moreover, Hamann and Reichmuth (1990) observed a compensatory increase in milk production of CM quarters during midlactation and late lactation that occurred rapidly and was maintained after treatment was discontinued. In the current study, about 92 to $98 \%$ of the difference in mean milk production between the control and TRT cows could be accounted for by the observed difference in milk produced by the 30-d and 70-d dry half udders in the TRT group cows. This does not prove that the 70-d half udder produced the amount of milk that it would have if both half udders had been given the same 70-d dry period. It could have been greater, the same, or even less than would have occurred if both half udders had been dried $70 \mathrm{~d}$ before ECD.

It is interesting that no differences in milk production responses of primiparous and multiparous cows were seen during the subsequent lactation, which agreed with results of Sorensen and Enevoldsen (1991) and Rastani et al. (2005). They did not obtain any evidence that first-lactation cows responded differently to dry period length than did other cows. These results differ from those of Annen et al. (2004b) who observed that primiparous cows given a 30-d dry period between first and second lactations and supplemented with bST (label-use) produced about $87 \%$ as much milk in the subsequent lactation as primiparous cows managed the same but given a 60-d dry period. In contrast, multiparous cows given a 30-d dry period produced as well as those given a 60-d dry period. Annen et al. (2004b) speculated that primiparous cows were more sensitive to dry period length because both body and mammary growth were still occurring. Differences among studies also may have been associated with the greater level of milk production per cow and due to different cow management. In the current study, the distribution of cows in the TRT group across the 3 parity groups considered was similar and all cows were managed similarly. An extensive series of statistical analyses that compared total udder milk production, half-udder milk production, and the relative proportion of milk produced by the 30-d and 70-d dry half udders during the different periods that were considered physiologically important did not detect differences due to parity. It is likely that a greater number of cows and better distribution of cow numbers in the 3 parity groups, especially in the control group, would be needed to detect any effects of parity between the control and TRT groups of cows if they existed. However, this does not compromise the results observed for the half-udder study using the cows in the TRT group.

Based on our hypothesis and published results of between-cow studies, it is clear that the decrease in 30 d dry half-udder milk production and total milk production of TRT group cows during the first 100 DIM was much greater than expected. When milk production of 30-d dry half udders or udders was evaluated during different stages of lactation it was observed that production responses differed during early vs. later lactation. For example, in between-cow studies, cows given a 30- 
d dry period produced the same amount of milk during lactation as those given 60-d dry periods (Schairer, 2001; Bachman, 2002; Gulay et al., 2003; Annen et al. 2004b; Rastani et al., 2005). Yet, when the mean daily milk production of 30-d dry cows was evaluated during the first 2 mo of lactation, it was less than for 60-d dry period cows (Lotan and Adler, 1976). This was similar to that seen in the current study during the first 80 or 100 DIM, whereas no reduction was seen during 80 to 150 DIM. In contrast, no differences in early lactation milk production (3 to $70 \mathrm{DIM}$ ) or 305 -d ME milk production were detected for cows given 30- or 60-d dry periods (Gulay et al., 2003) or when milk production of cows was compared following 30-, 50-, and 70-d dry periods (Sorensen and Enevoldsen, 1991). Therefore, some between-cow studies showed different milk production responses when early or later periods of the same lactation were evaluated. In the study of Gulay et al. (2003) and in the current study, cows were supplemented with $\mathrm{bST}$, albeit different amounts (10 mg of bST/d vs. 500 $\mathrm{mg} / 14 \mathrm{~d}$, respectively) and beginning either prepartum or at 80 DIM. Furthermore, the number of daily milkings $(2 \times$ or $3 \times / d)$ and thus, intervals between milkings differed during early but not during mid- and late lactation in these 2 studies. Overall, these milk production results suggested differences in functionality and total numbers of mammary cells in respective udders or half udders and that milk production likely could be affected by dry period and animal management.

Cow feeding and management should not have affected the 2 half udders in the same cow differently. Similar trends in BW and BCS indicated that nutritional effects probably were not responsible for differences seen in milk production by the half udders, a conclusion supported by a number of authors (Annen et al., 2004a,b). Moreover, mastitis incidence and severity were low and not more prevalent in either the control or the treatment group of cows. This leads to the conclusion that these factors did not negatively or differently affect cows in this half-udder study or directly account for differences in half-udder milk production. Reduced milk production during early but not late lactation and apparent reduced physical size of the 30-d half udders compared with the 70-d dry half udders indicated that differences likely existed in development or functionality of the 2 half udders of the same cow when 2 concurrent dry periods were evaluated. These differences likely occurred during the 70-d dry period and during lactation.

Because numbers and activity of mammary epithelial cells (MEC) are important to the level and persistency of milk production during lactation (Capuco et al., 2001, 2003 ), it is appropriate to briefly consider mammary cell dynamics during late lactation, the dry period, and subsequent early and later lactation. It also is worthwhile to consider some possible effects of concurrent 70-d and 30-d dry periods in the same udder and cow that can help us to understand and explain, at least in part, the results obtained. During the dry period, proliferation and turnover of MEC may have been reduced in the 30-d, because some half udders showed reduced size compared with the 70-d half udders and overall were less capable of producing milk during early lactation (3 to $100 \mathrm{DIM}$ ). No data were collected to allow the mechanisms responsible for these findings to be identified. However, the slower increase in milk production by half udders given a 30-d dry period, coupled with ability of the whole udder of the TRT group cows to produce similar amounts of milk as the control cows beyond $100 \mathrm{DIM}$, and perhaps during the whole lactation, allows at least 3 interpretations to be proposed.

First is the possibility that there were fewer MEC formed and retained in the 30-d half udders because of the shorter dry period and effects, if any, of drying the 70-d half udders. If this occurred, then there likely would be less replacement of senescent cells in the 30-d half-udder at the beginning of the subsequent lactation. This could have occurred because of local effects brought about by milking the 30-d half udder and the associated effects of the hormones and growth factors of pregnancy. Secondly, it is possible that there were a greater number of MEC in the 30-d dry half udder that did not differentiate fully in response to the events of parturition and $2 \times / d$ milking during the early phase of the lactation. This assumes that there was a greater pool of resting cells at parturition that were capable of differentiating but did not achieve functional status until peak lactation and thereafter. There was some evidence that milk production of the 2 half udders was less different at 100 DIM when milk production of individual half udders was discontinued. This suggests a delayed but positive effect on cell functionality or numbers of cells beginning at or beyond 80 DIM that was largely or only true for the 30 -d half udder. The changes suggested for later development of functionality of MEC in the 30-d dry half udders would be somewhat analogous to the apparent delay in differentiation and synthetic capacity of MEC and time to reach peak lactation by many cows induced into lactation using supra-physiological amounts of reproductive steroids (Head, 1999). A third possibility is that during early lactation, and probably midlactation and thereafter, there was a compensatory increase in milk production by the 70-d half udder, but little or no change in relative milk production by the 30-d half udder. This would have lasted through at least 100 DIM, at which time individual milk production measures of the 2 half udders were discontinued. In each of these scenarios, proliferation, turnover, and 
functional differentiation of the MEC in the 70-d dry half udder occurred essentially as expected, because of favorable local and systemic effects on mammary tissues. On the other hand, continued milking of the opposite half udder for an additional $40 \mathrm{~d}$ somehow blunted the proliferation and differentiation of mammary cells, which may have been due to altered local and systemic stimuli and the shorter time for regenerative involution to be completed.

Blunted cell proliferation during the dry period could have resulted in a greater proportion and carryover of senescent cells at the beginning of the subsequent lactation in the 30-d half udders. An increase in the population of "old" cells in the udder of CM cows was proposed as a way to explain reduced milk production of these cows compared with those given a 60-d dry period (Annen et al., 2004b). They assumed that these old cells would have lower proliferative and synthetic capacity, which would cause a premature decline in numbers of MEC during lactation and account for the reduction in milk production by CM cows. Trends in milk production responses of the 30-d and 70-d dry half udders of the TRT group of cows in the current study would only support a real difference in the proportion of these cells in scenarios where reduced cell proliferation and numbers were proposed.

Based upon these considerations, we speculate that increased milk production following parturition in cows milked $2 \times / \mathrm{d}$ was due to greater numbers of cells that had differentiated and gained functionality rather than accretion of additional MEC. Possible reasons for the difference in the developmental state of cells in the 2 half udders of the same cow cannot be determined.

Clearly, the within-cow half-udder experimental approach to evaluate $30-\mathrm{d}$ and $70-\mathrm{d}$ dry periods on milk production in the same cow resulted in reduced ability of the half udders that were dry for $30 \mathrm{~d}$ to produce milk (Capuco and Akers, 1999). In fact, based on reduced early but not complete lactation milk production trends, and apparent reduced size of that half udder in some cows, the dynamics of cell turnover, accretion, or synthetic capacity seem to have been affected adversely in the 30-d half udder or conversely, beneficially in the $70-d$ half udder. Because of differences in milk production responses of cows using the 30-d and 70-d halfudder model compared with between-cow comparisons (Schairer, 2001; Bachman, 2002; Gulay et al., 2003; Annen et al., 2004b; Rastani et al., 2005), we conclude that the half-udder within-cow model may not be appropriate to evaluate adequacy of a 30-d dry period in cows. Reasons for different milk production responses were not identified, but undoubtedly are complex and involve both local and systemic effects on the mammary glands.
These factors likely affected the ability of the 2 half udders to function at the same level during lactation.

\section{CONCLUSIONS}

Results obtained using the within-cow half-udder experimental model do not agree with the consensus of recent between-cow studies that shortening dry period length from 60 to $30 \mathrm{~d}$ will not cause a significant reduction in milk production during the subsequent lactation. The $18.9 \%$ decrease in milk production by the 30 $\mathrm{d}$ dry half udders relative to the 70-d dry half udders greatly exceeded the 0 to $3.6 \%$ decreases observed between 30-d and 60-d dry-cow groups. The within-cow half-udder model may not be an appropriate model to compare the efficacy of different dry period lengths in dairy cattle. However, both the half-udder and withincow comparative characterization of 30- and 70-d half udders that produced markedly different outcomes for milk production may be of value in gaining a greater understanding of events associated with mammary gland growth and function, especially during the dry period and early lactation.

\section{ACKNOWLEDGMENTS}

Financial assistance of this research was by the milk check-off funded by Florida and Georgia members of Southeast Milk, Inc. The efforts of David Bray and James Parker in procuring the milking claw assemblies are appreciated, as was the cooperation extended to us by the milking staff and others at the UF/IFAS Dairy Research Unit (Gainesville, FL).

\section{REFERENCES}

Annen, E. L., R. J. Collier, M. A. McGuire, and J. L. Vicini. 2004a. Effects of dry period length on MY and mammary epithelial cells. J. Dairy Sci. 87(E. Suppl.):E66-E76.

Annen, E. L., R. J. Collier, M. A. McGuire, J. L. Vicini, J. M. Ballam, and M. J. Lormore. 2004b. Effect of modified dry period lengths and bovine somatotropin on yield and composition of milk from dairy cows. J. Dairy Sci. 87:3746-3761.

Bachman, K. C. 2002. Milk production of dairy cows treated with estrogen at the onset of a short dry period. J. Dairy Sci. 85:797-803.

Bachman, K. C., and M. L. Schairer. 2003. Bovine studies on optimal lengths of dry periods. J. Dairy Sci. 86:3027-3037.

Capuco, A. V., and R. M. Akers. 1999. Mammary involution in dairy animals. J. Mammary Gland Biol. Neoplasia 4:137-144.

Capuco, A. V., S. E. Ellis, S. A. Hale, E. Long, R. A. Erdman, X. Zhao, and M. J. Paape. 2003. Lactation persistency: Insights from mammary cell proliferation studies. J. Anim. Sci. 82(Suppl. 3):18-31.

Capuco, A. V., D. L. Wood, R. Baldwin, K. McLeod, and M. J. Paape. 2001. Mammary cell number, proliferation and apoptosis during the lactation cycle: Relationship to milk production and effect of bST. J. Dairy Sci. 84:2177-2187.

Ferguson, J. D., D. T. Galligan, and N. Thomsen. 1994. Principal descriptors of body condition score in Holstein cows. J. Dairy Sci. 77:2695-2703. 
Grummer, R. R., and R. R. Rastani. 2004. Why re-evaluate dry period length? J. Dairy Sci. 87(E. Suppl.):E77-E85.

Gulay, M. S., M. J. Hayen, K. C. Bachman, T. Belloso, M. Liboni, and H. H. Head. 2003. Milk production and feed intake of Holstein cows given short ( $30 \mathrm{~d})$ or normal ( 60 d) dry periods. J. Dairy Sci. 86:2030-2038.

Gulay, M. S., M. J. Hayen, M. Liboni, T. I. Belloso, C. J. Wilcox, and H. H. Head. 2004. Low doses of bovine somatotropin during the transition period and early lactation improves milk yield, efficiency of production, and other physiological responses of Holstein cows. J. Dairy Sci. 87:948-960.

Hamann, J., and J. Reichmuth. 1990. Compensatory milk production within the bovine udder: Effects of short-term non-milking of single quarters. J. Dairy Res. 57:17-22.

Head, H. H. 1999. Artificial induction of lactation. Chapter 10. Pages 227-260 in Biology of Lactation. J. Martinet, L.-M. Houdebine, and H. H. Head, ed. INRA, Paris, France.

Kuhn, M. T., and J. L. Hutchison. 2005. Methodology for the estimation of days dry effects. J. Dairy Sci. 88:1499-1508.

Littell, R. C., G. A. Milliken, W. W. Stroup, and R. D. Wolfinger. 2000. SAS system for mixed models. SAS Institute, Inc., Cary, NC.
Lotan, E., and J. H. Adler. 1976. Observations on the effect of shortening the dry period on milk yield, body weight, and circulating glucose and FFA levels in dairy cows. Tijdschr. Diergeneesk. 10:77-82.

Rastani, R. R., R. R. Grummer, S. J. Bertics, A. Gumen, M. C. Wiltbank, D. G. Mashek, and M. C. Schwab. 2005. Reducing dry period length to simplify feeding transition cows: Milk production, energy balance, and metabolic profiles. J. Dairy Sci. 88:10041014.

Remond, B., J. Rouel, N. Pinson, and S. Jabet. 1997. An attempt to omit the dry period over three consecutive lactations in dairy cows. Ann. Zootec. 46:399-408.

SAS Institute. 1991. SAS User's Guide. Statistics. Vol 5. SAS Inst., Inc., Cary, NC.

Schairer, M. L. 2001. Estrogen treatments for the initiation of dryoff in dairy cows. M.S. Thesis. Univ. Florida, Gainesville.

Smith, A., J. V. Wheelock, and F. H. Dodd. 1967. Effect of milking throughout pregnancy on milk secretion in the succeeding lactation. J. Dairy Res. 34:145-150.

Sorensen, J. T., and C. Enevoldsen. 1991. Effect of dry period length on milk production in subsequent lactation. J. Dairy Sci. 74:1277-1283. 